\title{
Relationship between different stages of the corpus luteum and the expression of the peroxisome proliferator-activated receptor $\gamma$ protein in bovine large lutein cells
}

\author{
T. Viergutz, B. Loehrke, R. Poehland, F. Becker and W. Kanitz \\ Research Institute for the Biology of Farm Animals, Dummerstorf, Germany
}

\begin{abstract}
Lutein cells produce progestins that support pregnancy. Steroidogenesis requires coordination of the anabolic and catabolic pathways of lipid metabolism. Peroxisome proliferator-activated receptors (PPAR) are transcription factors that are central in the regulation of lipid metabolism. Hence, they may play a role in regulation of the development and regression of the corpus luteum. The present study investigated the expression of PPAR- $\gamma, \mathrm{n}$ during different stages of the corpus luteum. Lutein cells were isolated mechanically from non-pregnant and pregnant heifers on days 5, 12 and 20 of the oestrous cycle $(n=3$ for each day). PPAR- $\gamma$ in single cells was analysed by flow cytometry. PPAR- $\gamma_{1}$ and PPAR- $\gamma_{2}$ isoforms were distinguished by immunoblotting. The cell cycle of the lutein cells was measured by the flow cytometric quantification of DNA in single cells, using propidium iodide staining after ethanol fixation and RNAse treatment, and by the detection of the proliferating cell nuclear antigen (PCNA). The response of the cells to PPAR- $\gamma$ agonist $15-$ deoxy- $\Delta^{12,14}$ prostaglandin $\mathrm{J}_{2}\left(15 \mathrm{dPGJ}_{2}, 200\right.$ and $490 \mathrm{nmol} \mathrm{l}^{-1}$ ) with and without changing the cell cycle by the anti-apoptogenic drug aurintricarboxylic acid (ATA, $10 \mu \mathrm{mol} \mathrm{l}^{-1}$ ) was used as an in vitro model to study the relationship between the cell cycle and PPAR- $\gamma$. The concentration of PPAR- $\gamma$ per cell from non-pregnant heifers was significantly higher on day $5(3.40 \pm 0.30 \mathrm{fmol})$ compared with that on day $12(1.34 \pm 0.18 \mathrm{fmol}, P<0.05)$ and day $20(0.55 \pm 0.2 \mathrm{fmol}$, $P<0.05)$. In pregnant heifers, the concentration of PPAR $-\gamma$ was significantly $(P<0.01)$ higher than in non-pregnant heifers. A decrease in the PPAR- $\gamma_{1}$ isoform relative to PPAR- $\gamma_{2}$ was observed in cells on day 12 of the oestrous cycle compared with day 5 . The cell cycle (S phase portion in cells on days 5, 12 and 20: $16 \pm 4 \%, 6 \pm 4 \%$ and $4 \pm 3 \%$, respectively) and the portion of cells with PCNA correlated with the amount of PPAR- $\gamma$ in non-pregnant heifers. ATA promoted the $S$ phase in cells of non-pregnant heifers (day 12) and the endogenous agonist of PPAR- $\gamma, 15 \mathrm{dPGJ}_{2}$, inhibited the response to ATA in a dose-dependent manner, indicating that PPAR- $\gamma$ plays a role in the arrest of the cell cycle in lutein cells to maintain their differentiated state.
\end{abstract}

\section{Introduction}

The corpus luteum develops from ovarian follicular mesenchymal thecal and epithelial granulosa cells to small and large lutein cells (Juengel et al., 1993; Monniaux et al., 1994). During differentiation, the luteinizing cells stop synthesizing oestrogen but maintain and increase the production of progestins (Selvaraj et al., 1994; Nicosia et al., 1995), chiefly 20 $\alpha$-dihydroprogesterone (Bowen et al., 1996). The differentiation of granulosa cells to large lutein cells is associated with a marked increase in metabolic functions which are characterized by increased activity of mitochondrial enzymes (Doody et al., 1990; Richards and

Received 18 May 1999.
Almond, 1994) to meet the energy requirements for the production of steroids. The increase in the expression of enzymes, required for the synthesis of progestins from cholesterol, is linked to increasing amounts of mRNA species encoding enzymes involved in cholesterol metabolism and to the expression of novel mitochondrial enzymes (Doody et al., 1990). The alteration of the expression of steroidogenic enzymes is regulated by hormones and other factors, such as insulin, insulin-like growth factor I, LH, transforming growth factor $\beta$, and their receptors (Monniaux et al., 1994). The differentiation is also accompanied by the expression of receptors involved in the uptake of lipids (Funkenstein et al., 1984). They provide substrates for the steroid synthesis in granulosa and luteinizing cells and the energy required for steroid synthesis from the $\beta$-oxidation of fatty 
acids (Funkenstein et al., 1984; Amsterdam and Rotmensch, 1987).

The mechanisms underlying the alteration of gene expression in luteinizing granulosa cells are not completely understood. It has been reported (Pall et al., 1997; Sterneck et al., 1997; Löhrke et al., 1998) that transcription factors are involved, which mediate the transduction of hormonal signals, including those arising from lipids, to targets at the DNA. A group of transcription factors, the peroxisome proliferator-activated receptors (PPAR) $\alpha$ and $\gamma$, are thought to be key regulators in cellular lipid homeostasis (Kliewer et al., 1997) which requires co-ordination between peroxisomes and mitochondria during steroidogenesis (Mendis-Handagama et al., 1995). PPAR- $\gamma$ regulates the expression of genes encoding enzymes of the cholesterol synthesis pathway, such as 3-hydroxy-3-methylglutaryl-CoA synthase (Rodriguez et al., 1994) and lipoprotein lipase (Schoonjans et al., 1996) which mediates uptake of fatty acids and cholesterol.

In contrast to PPAR- $\gamma$, the expression of PPAR- $\alpha$ is regulated by glucocorticoids (Lemberger et al., 1994). The transcription factor $\mathrm{C} / \mathrm{EBP}_{\beta}$, a member of the CCAAT enhancer binding protein $(\mathrm{C} / \mathrm{EBP})$ family, stimulates the expression of PPAR- $\gamma$ (Wu et al., 1995). In turn, the $C / \mathrm{EBP}_{\beta}$ gene is regulated by gonadotrophins and is the only known transcription factor that is induced promptly in response to an ovulatory dose of $\mathrm{LH}$ and to the LH surge naturally occurring during ovulation in many species (Pall et al., 1997; Sterneck et al., 1997). $\mathrm{C} \mathrm{EBP}_{\beta}$ stimulates not only the expression of PPAR- $\gamma$ but also, in co-operation with $\mathrm{C} / \mathrm{EBP}_{\alpha^{\prime}}$ of cyclooxygenase 2 , also called prostaglandin endoperoxide synthase 2 (Sirois and Richards, 1993), which is important in the production of prostaglandins from arachidonic acid metabolism (Reginato et al., 1998).

PPAR- $\gamma$ is activated by binding arachidonic acid and type $D_{2}$ prostaglandins (Kliewer et al., 1997) of which 15-deoxy- $\Delta^{12,14}$ $\mathrm{PGJ}_{2}\left(15 \mathrm{dPGJ}_{2}\right.$ ) is the most potent (Forman et al., 1995), whereas $\mathrm{PGF}_{2 \alpha}$ antagonizes the action of PPAR- $\gamma$ via stimulation of phosphorylating pathways (Reginato et al., 1998). C/EBP forms are expressed in ovarian cells, including in the granulosa layer of preovulatory antral follicles (Piontkewitz et al., 1996; Sterneck et al., 1997). C/EBP ${ }_{\beta}$-deficient ovaries lack corpora lutea and fail to downregulate expression of the prostaglandin endoperoxidase synthase 2 and P450 aromatase genes in response to gonadotrophins (Sterneck et al., 1997).

A regulatory role of PPAR- $\gamma$ in the regression of the corpus luteum may occur not only at the intracellular lipid homeostasis but also at the interaction between luteal and non-luteal cells which also express PPAR- $\gamma$, including macrophages (Xing et al., 1997), vascular endothelial and smooth muscle cells (Marx et al., 1998; Satoh et al., 1999). Activation of PPAR- $\gamma$ blocks the cell cycle in vascular cells and inhibits the expression of genes encoding vasoconstrictive factors in endothelial cells (Marx et al., 1998; Satoh et al., 1999). Thus, a high concentration of PPAR- $\gamma$ may promote the circulatory supply of the corpus luteum, whereas it may prevent vascularization. A decrease in the PPAR- $\gamma$ proteins due to downregulation of the activity of macrophages by increasing concentrations of progesterone (Sugino et al., 1996) and, as a corollary, a reduction in potent
PPAR- $\gamma$ agonists could result in abrogation of the suppression of vasoconstrictive endothelial activity, leading to circulatory malfunction and, therefore, to functional regression. There are two isoforms of the PPAR- $\gamma$ protein: PPAR- $\gamma_{1}$ and PPAR- $\gamma_{2}$ (Forman et al., 1995; Kliewer et al., 1995). Three PPAR- $\gamma$ mRNAs $\left(\gamma_{1}, \gamma_{2}\right.$ and $\left.\gamma_{3}\right)$ give rise to two proteins; the translation products of $\gamma_{1}$ and $\gamma_{3}$ mRNA are indistinguishable (Fajas et al., 1998). Little is known about the function of the two proteins transcribed from the PPAR- $\gamma$ gene because detailed side by side comparison of activation by the transcription factors PPAR- $\gamma_{1}$ and $-\gamma_{2}$ has not been performed in mammalian cells (Fajas et al., 1998), including those from the corpus luteum.

To date, there has only been one study on the expression and function of PPAR- $\gamma$ proteins in lutein cells Löhrke et al. (1998). The known functions of PPAR- $\gamma$ in non-luteal cells listed above indicate a role of the transcription factor in the co-ordinated development of the cellular metabolic compartments that provide lutein cells with substrates for steroidogenesis. Enhanced steroidogenesis is accompanied by a loss of lutein cell cycle activity (Fields et al., 1992). The steroidogenesis ceases and the corpus luteum regresses when fertilization does not take place. The corresponding regulatory events are poorly understood. It is hypothesized that the expression rate of PPAR- $\gamma$ is linked to the developmental stages of the corpus luteum. Hence, in the present study, the expression of PPAR $-\gamma$ protein in relation to the cell cycle activity during different stages of the corpus luteum was investigated.

\section{Materials and Methods}

\section{Materials}

PPAR- $\gamma$ antibodies to the amino acid sequence 284-298 of the PPAR- $\gamma$ protein were purchased from Cayman-Alexis (Grünberg). Standards beads for the calibration of fluorescence intensities were obtained from FCSC (Leiden). All other chemicals, hormones and antibodies were from Sigma (Deisenhofen), unless stated otherwise.

\section{Animals}

Dairy heifers at 18-20 months old and weighing between 430 and $470 \mathrm{~kg}$ were used in the experiments. Heifers with a regular oestrous cycle (day 5 , day 12 , day 20 , oestrus $=$ day 0 ) were used. Detection of oestrus was performed twice a day. In addition, rectal palpation of the ovaries and ultrasonic diagnosis were conducted to gain more information on the stage of the oestrous cycle.

Pregnant heifers (day $0=$ oestrus + artificial insemination) were killed on days 5,12 and 20 (three animals on each day).

\section{Lutein cell preparation}

Corpora lutea were obtained by ovariectomy performed on days 5, 12 and 20 (three animals on each day) of the 
oestrous cycle (oestrus = day 0 ) in cows anaesthetized by epidural and local anaesthesia in accordance with the German Federal Law for Care of Animals. In experiments to test the effect of $\mathrm{PGF}_{2 \alpha}$ on PPAR- $\gamma$ expression, the animals were treated on day 4 with cloprostenol (aniMedica, Bernburg) at a dose of $1.4 \mu \mathrm{g} \mathrm{kg}-1$ and corpora lutea were collected after $12 \mathrm{~h}$. Functional regression was confirmed by measuring the progesterone concentration, which decreased significantly (1.4-fold the carrier-treated control, $P<0.05$ ) in response to the drug. The corpora lutea were surgically removed from the ovaries and were dissociated mechanically to minimize the contamination of lutein cells with other types of cell expressing PPAR- $\gamma$. The number of lutein cells per mass of corpus luteum on days 5 and 12 was $6.9 \times 10^{5}$ and $3.8 \times 10^{5}$ cells $\mathrm{g}^{-1}$, respectively. More rigorous dissociation using both mechanical and enzymatic techniques did not yield significantly greater numbers of lutein cells. The tissue was placed on gauze ( $40 \mu \mathrm{m}$ pores), minced, and gently ground using a glass rod, covering the tissue with Ham's F12 medium buffered with Hepes ( $25 \mathrm{mmol} \mathrm{l}^{-1}, \mathrm{pH} 7.4$ ) and containing 2 mmol EDTA $\mathrm{l}^{-1}$ to facilitate cell dissociation. The cell suspension was filtered, the cells were separated by centrifugation ( $200 \mathrm{~g}, 10 \mathrm{~min})$, and the erythrocytes were lysed by resuspending the cells in water. The lysis was stopped after $10 \mathrm{~s}$ by the addition of concentrated saline to achieve $0.85 \%(\mathrm{w} / \mathrm{v})$ saline. After centrifugation, the cells were resuspended in serum-free EDTA-free Hepes-buffered Ham's F12 medium with $10 \mathrm{ng}$ insulin $\mathrm{ml}^{-1}$ (culture medium). The proportions of large and small lutein cells separated by flow cytometry were $60 \pm 10$ and $25 \pm 8 \%$ of the total cellular counts used in culture. In the analysis, the percentage of large lutein cells increased $>95 \%$ by gating the cells in the flow cytometric histogram. Cell density was determined using a cell counter (Coulter, Krefeld) and cell viability by exclusion of trypan blue or $40 \mu \mathrm{mol}$ propidium iodide $\mathrm{l}^{-1}$. Uptake of propidium iodide was checked by flow cytometry; the viability was $>95 \%$.

\section{Flow cytometry}

Quantitative analysis of cellular fluorescence was performed by flow cytometry to analyse the cells simultaneously according to size, granularity, LH receptors and PPAR- $\gamma$ expression (proportion of cells expressing PPAR- $\gamma$, and PPAR- $\gamma$ content per cell). The analysis of LH receptors was carried out according to the method of Fields et al. (1992) and the flow cytometric analysis was conducted as described by Löhrke et al. (1997). Briefly, an argon laserequipped flow cytometer (Coulter-Elite, Krefeld) recording emissions of multiple fluorescence (green, orange, red) excited at $488 \mathrm{~nm}$ (counting 5000 cells) was used. Cells of interest were identified by three successive steps: (i) by establishing a histogram on the basis of cell size and granularity; (ii) by establishing the fluorescence histogram; and (iii) by projecting the fluorescence into the size-granularity histogram. The cells were gated and the proportion of cells and their fluorescence intensity arising from a second fluorogenic label were automatically calculated.

\section{Cell cycle analysis by flow cytometry}

Freshly prepared and cultured cells (days 5, 12 and 20 of the oestrous cycle) were used. The cultured cells were incubated for $24 \mathrm{~h}$ at $37^{\circ} \mathrm{C}$ in culture medium with the solvent and with the effectors $15 \mathrm{dPGJ}_{2}$ and ATA. A stock solution of $15 \mathrm{dPGJ}_{2}$ dissolved in methylacetate was diluted with 5 mmol sodium phosphate $1^{-1}(\mathrm{pH} 7.1)$ and ATA was dissolved in $50 \mathrm{mmol} \mathrm{NaHCO} \mathrm{l}^{-1}$. The solutions were added (1 volume to 20 volumes of the culture medium) in final concentrations of 200 and $490 \mathrm{nmol} 15 \mathrm{dPGJ}_{2} \mathrm{l}^{-1}(0.01 \%(\mathrm{v} / \mathrm{v})$ methylacetate) and $10 \mu \mathrm{mol}$ ATA $1^{-1}$. Freshly prepared and cultured cells were fixed in ethanol (70\%), washed and treated with RNAse solution (100 $\mathrm{U} \mathrm{ml}^{-1}$ in $\mathrm{PBS}, 37^{\circ} \mathrm{C}$, $30 \mathrm{~min})$. The RNAse solution was heated $\left(85^{\circ} \mathrm{C}, 60 \mathrm{~min}\right)$ to denature DNAse contamination (Stöhr et al., 1978). After incubation for $30 \mathrm{~min}$ with propidium iodide $\left(70 \mu \mathrm{mol} \mathrm{l}^{-1}\right)$ in HBS (5 mmol Hepes $1^{-1}$, pH 7.3, 150 mmol $\mathrm{NaCl} \mathrm{l}^{-1}$ ), flow cytometry was performed (Coulter-Elite) and the cell cycle was analysed using a computer-aided multicycle program (Phoenix of the program package of the flow cytometer).

\section{Detection of proliferating cell nuclear antigen}

Cells were fixed in ethanol $(70 \%, \mathrm{v} / \mathrm{v})$, washed and treated with RNAase $\left(1 \mathrm{mg} \mathrm{ml}^{-1}\right.$ in PBS, $\left.37^{\circ} \mathrm{C}, 30 \mathrm{~min}\right)$ as described above. The cells were incubated with purified monoclonal $\operatorname{IgG}_{2 a}$ mouse antibody against PCNA (final concentration $5 \mu \mathrm{g} \mathrm{ml}^{-1}$ ) in the dark for $1 \mathrm{~h}$ at room temperature. The antibody was conjugated with fluorescein isothiocyanate isomer (FITC). A negative control was obtained by incubating the cells with an non-specific mouse $\operatorname{IgG}_{2 a}$-FITC conjugate (final concentration $5 \mathrm{mg} \mathrm{l}^{-1}$; both antibodies from DAKO, Hamburg). After incubation, the cells were washed by centrifugation at $350 \mathrm{~g}$ for $5 \mathrm{~min}$, re-suspended with DNA staining medium (propidium iodide, $70 \mu \mathrm{mol} \mathrm{1^{-1 }}$, in HBS) and incubated in the dark for $30 \mathrm{~min}$ at room temperature. After washing and centrifugation at $350 \mathrm{~g}$ for $5 \mathrm{~min}$, the cells were resuspended in HBS and the dual fluorescence was analysed by flow cytometry.

\section{PPAR- $\gamma$ immunofluorescence}

Lutein cells were fixed in methanol $\left(-20^{\circ} \mathrm{C}\right)$ for $4 \mathrm{~min}$, using one volume of cell suspension and ten volumes of methanol. The cells were centrifuged $\left(150 \mathrm{~g}, 4^{\circ} \mathrm{C}, 5 \mathrm{~min}\right)$, re-suspended in PBS containing $0.2 \%(\mathrm{w} / \mathrm{v})$ BSA $(\mathrm{pH} 7.4)$ and aliquots were plated (24-well plastic microplates). The cells were incubated $\left(1 \mathrm{~h}, 22^{\circ} \mathrm{C}\right)$ with rabbit-anti-PPAR- $\gamma$ antibodies used in a final concentration of $2.5 \mu \mathrm{g} \mathrm{ml}^{-1}$. The unbound antibodies were washed out and the cells were incubated for $1 \mathrm{~h}$ at $22^{\circ} \mathrm{C}$ with phycoerythrine-conjugated anti-rabbit $\mathrm{F}\left(\mathrm{ab}^{\prime}\right)_{2}$ antibody fragments (PBS, $\mathrm{pH} \mathrm{7.2,0.2 \%}$ $(\mathrm{w} / \mathrm{v})$ BSA) or with FITC-conjugated anti-rabbit-F $\left(\mathrm{ab}^{\prime}\right)_{2}$ antibody fragments (PBS, pH 7.4, $0.2 \%(w / v)$ BSA). After washing by centrifugation at $150 \mathrm{~g}, 4^{\circ} \mathrm{C}, 5 \mathrm{~min}$ and resuspension in PBS ( $\mathrm{pH} 7.4,0.2 \%(\mathrm{w} / \mathrm{v})$ BSA), the cells were analysed by flow cytometry. A control of the non-specific 
fluorescence was obtained by omitting the PPAR- $\gamma$-specific antibody. The corresponding value was automatically subtracted by the flow cytometer and the percentage of fluorescence-positive cells and the fluorescence intensity per cell were recorded. Quantification of the concentration of PPAR- $\gamma$ was carried out as described by Löhrke et al. (1998). Briefly, a calibration of the flow cytometric fluorescence intensity by standards beads (p26) was conducted and the fluorescence intensity of the cells was converted into concentrations with the aid of the calibration curve.

\section{Immunoblotting of PPAR- $\gamma_{1}$ and PPAR- $\gamma_{2}$ isoforms}

Cells (days 5, 12 and 20 of the oestrous cycle and days 5 and 12 after $\mathrm{PGF}_{2 \alpha}$ ) were lysed by cold aqueous $0.1 \%(\mathrm{w} / \mathrm{v})$ sodium citrate and $0.1 \%(\mathrm{v} / \mathrm{v})$ Triton-X100, and the lysate was fractionated by centrifugation $\left(240000 \mathrm{~g}, 1 \mathrm{~h}, 4^{\circ} \mathrm{C}\right)$. The supernatant of the ultracentrifugate was used immediately in PAGE and the separated proteins were blotted onto nitrocellulose as described by Löhrke et al. (1993). The nitrocellulose was blocked by horse serum $(5 \%, v / v)$ and PPAR- $\gamma$ was detected by rabbit anti-PPAR- $\gamma$ antibodies dissolved in the blot buffer containing $2.5 \%(\mathrm{v} / \mathrm{v})$ horse serum and used in a final concentration of $1 \mu \mathrm{g} \mathrm{ml} \mathrm{m}^{-1}$. The nitrocellulose was washed and incubated with peroxidase-conjugated anti-rabbit- $\mathrm{F}\left(\mathrm{ab}^{\prime}\right)_{2}$ according to the manufacturer's instructions (Sigma). The stain was developed by diaminobenzidine $\left(0.3 \%\right.$, w/v) and $\mathrm{H}_{2} \mathrm{O}_{2}$ $(0.01 \%, \mathrm{v} / \mathrm{v})$ in $100 \mathrm{mmol}$ Tris $1^{-1}, \mathrm{pH} \mathrm{7.2,} \mathrm{as} \mathrm{described} \mathrm{by}$ Löhrke et al. (1993, 1998). The bands were analysed by scanning the blots and densitometry (Herolab program package, Wiesloch).

\section{Statistical analysis}

Unless otherwise stated, experimental data are presented as the mean $\pm \mathrm{SD}$ of duplicate measurements of three independent experiments. ANOVA and Tukey's comparison methods were used for comparisons among multiple means.
Assessment of the significance of differences in relative data was accomplished by a paired $t$ test. Percentage data obtained by flow cytometry were analysed by chi-squared analysis (internal program package of the flow cytometer).

\section{Results}

\section{Corpus luteum morphology in relation to the lutein cell cycle}

The diameter of the corpus luteum increased from early dioestrus (day 5) to mid-dioestrus (day 12) and decreased with increasing age towards pro-oestrus (day 20) (Fig. 1a-c, insets). The results of the cell cycle analysis indicated the highest proportion of cells in S phase occurred on day 5 (16 \pm $4 \%, n=3)$. The proportion of cells in S phase decreased on day $12(6 \pm 4 \%, n=3)$ and the lowest proportion was observed on day $20(3 \pm 3 \%, n=3)$ (Fig. 1a-c).

The agonist of PPAR- $\gamma, 15 \mathrm{dPGJ}_{2}$, used at concentrations of 200 and $490 \mathrm{nmol} \mathrm{l}^{-1}$ did not affect the proportion of cells in S phase after incubation of lutein cells on day 12 of the

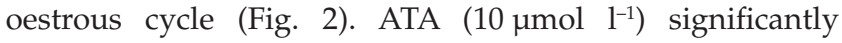
increased the proportion of cells in $S$ phase $(18 \pm 1 \%, P<$ $0.05, n=3$ ) after incubation with the drug for $24 \mathrm{~h}$. Activation of PPAR- $\gamma$ by $15 \mathrm{dPGJ}_{2}$ inhibited the stimulatory effect of ATA on the percentage of cells in S phase (Fig. 2).

\section{Relationship between PCNA and cellular DNA content}

The expression of PCNA protein was monitored in different phases of the cell cycle by dual fluorescence analysis involving immunostaining of the PCNA protein and the DNA stain arising from propidium iodide (Fig. 3). Measurement of the DNA content per cell indicated an increase in the proportion of cells in the G0/G1 phase with increasing age of the corpus luteum (Fig. 3). In this analysis, the control data from days 5 and 12 (three animals in each case) were pooled as they did not differ (Fig. 3). Quantitative results of the flow cytometric histograms (Fig. 3) are

Table 1. Relationship between DNA content and proliferating cell nuclear antigen (PCNA) in lutein cells from days 5 and 12 of the oestrous cycle in non-pregnant heifers

\begin{tabular}{|c|c|c|c|c|c|c|c|c|c|c|}
\hline $\begin{array}{c}\text { (a) } \\
\text { Quadrant }\end{array}$ & $\begin{array}{l}\text { Phase of the } \\
\text { cell cycle }\end{array}$ & $\begin{array}{l}\text { Percentage } \\
\quad( \pm \mathrm{SD})\end{array}$ & $\begin{array}{c}\text { (b) } \\
\text { Quadrant }\end{array}$ & $\begin{array}{l}\text { Phase of the } \\
\text { cell cycle }\end{array}$ & $\begin{array}{c}\text { PCNA } \\
(+/-)\end{array}$ & $\begin{array}{l}\text { Percentage } \\
\quad( \pm \text { SD })\end{array}$ & $\begin{array}{c}\text { (c) } \\
\text { Quadrant }\end{array}$ & $\begin{array}{l}\text { Phase of the } \\
\text { cell cycle }\end{array}$ & $\begin{array}{c}\text { PCNA } \\
(+/-)\end{array}$ & $\begin{array}{l}\text { Percentage } \\
\quad( \pm \text { SD })\end{array}$ \\
\hline I & $\mathrm{G}+\mathrm{S}+\mathrm{M}$ & $18 \pm 3$ & I & $\mathrm{G}+\mathrm{S}+\mathrm{M}$ & + & $27 \pm 5$ & I & $G+S$ & + & $13 \pm 3$ \\
\hline II & & 0 & II & & + & $11 \pm 5$ & II & M & + & $7 \pm 3$ \\
\hline III & $\mathrm{G}+\mathrm{S}+\mathrm{M}$ & $82 \pm 4$ & III & $\mathrm{G}+\mathrm{S}+\mathrm{M}$ & - & $55 \pm 4$ & III & $G+S$ & - & $72 \pm 4$ \\
\hline IV & & 0 & IV & & - & $7 \pm 3$ & IV & M & - & $8 \pm 3$ \\
\hline $\mathrm{I}+\mathrm{II}$ & $\mathrm{G}+\mathrm{S}+\mathrm{M}$ & $18 \pm 3$ & $\mathrm{I}+\mathrm{II}$ & $\mathrm{G}+\mathrm{S}+\mathrm{M}$ & + & $38 \pm 4$ & $\mathrm{I}+\mathrm{II}$ & $\mathrm{G}+\mathrm{S}+\mathrm{M}$ & + & $20 \pm 3$ \\
\hline
\end{tabular}

Cells, symbols and data are identical to those described in Fig. 3. In addition, + and - stand for PCNA-positive and -negative cells.

(a) Represents non-specific immunofluorescence (control), (b) and (c) represent data from days 5 and 12 of the oestrous cycle, respectively ( $n=3$ for each day). Quadrant I indicates the proportion of cells in G0/G1 phase (G) and S phase (S).

Quadrants II, III, IV represent the proportion of the cells showing the phases G2/M (M), G and M, with and without expression of PCNA protein, as illustrated in Fig. 3.

The differences (b) I- (a) I and (c) I - (a) I yield the PCNA-positive fraction (\%).

Only the difference (b) I + II - (a) I + II was significant $(20 \pm 3 \%, P<0.05)$. 

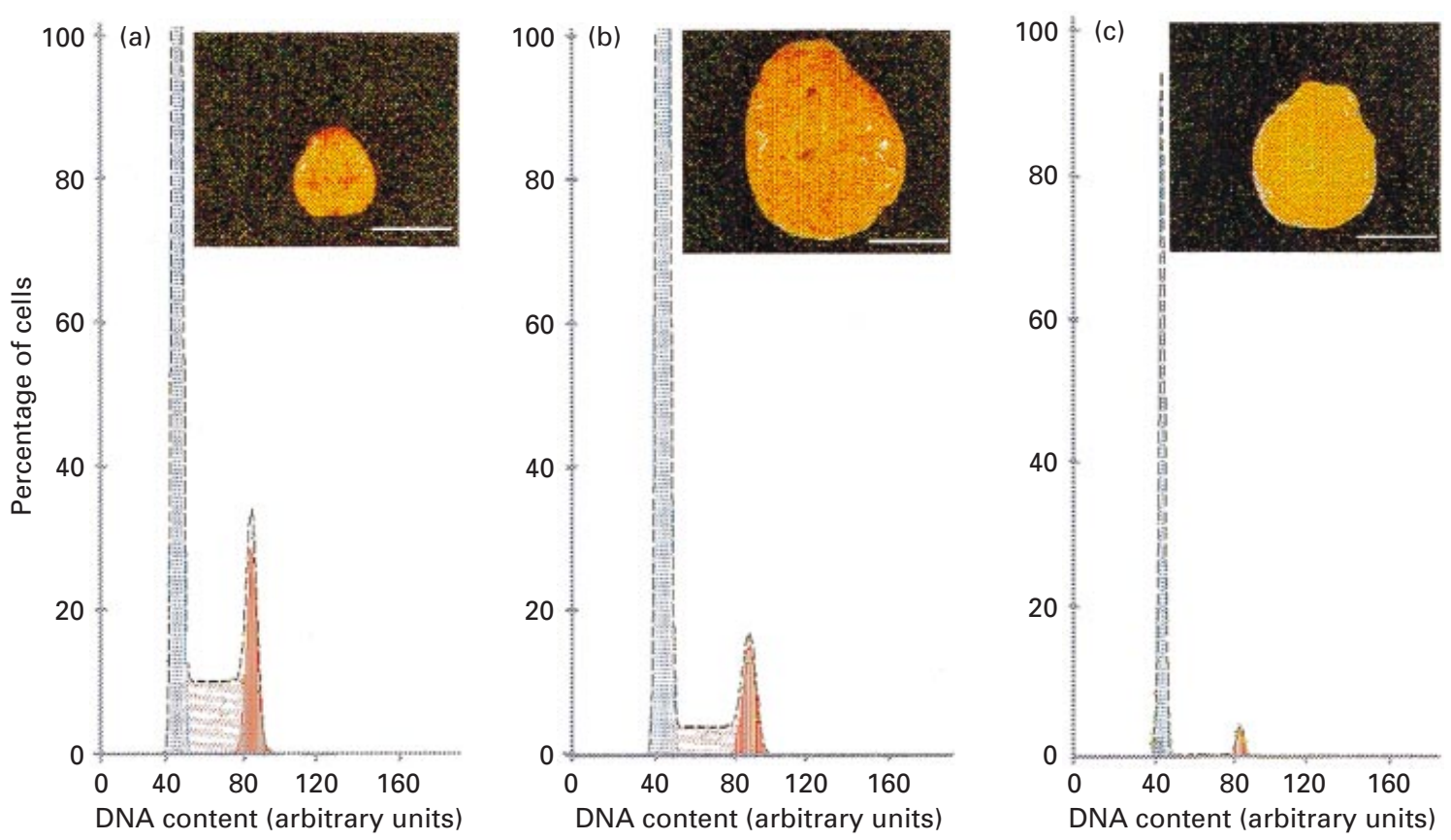

Fig. 1. Cell cycle analysis in large lutein cells from (a) day 5, (b) day 12 and (c) day 20 of the oestrous cycle in non-pregnant heifers (three animals in each group) showing the percentage of cells in S phase is dependent on development. Cell cycle analysis was conducted by propidium iodide staining and flow cytometry using the multicycle program. The blue peak, the pink region and the red peak indicate the percentage of cells in the G0/G1 phase, S phase and G2/M phase, respectively. The insets show the corresponding morphological changes of the corpus luteum. Scale bars represent $10 \mathrm{~mm}$.

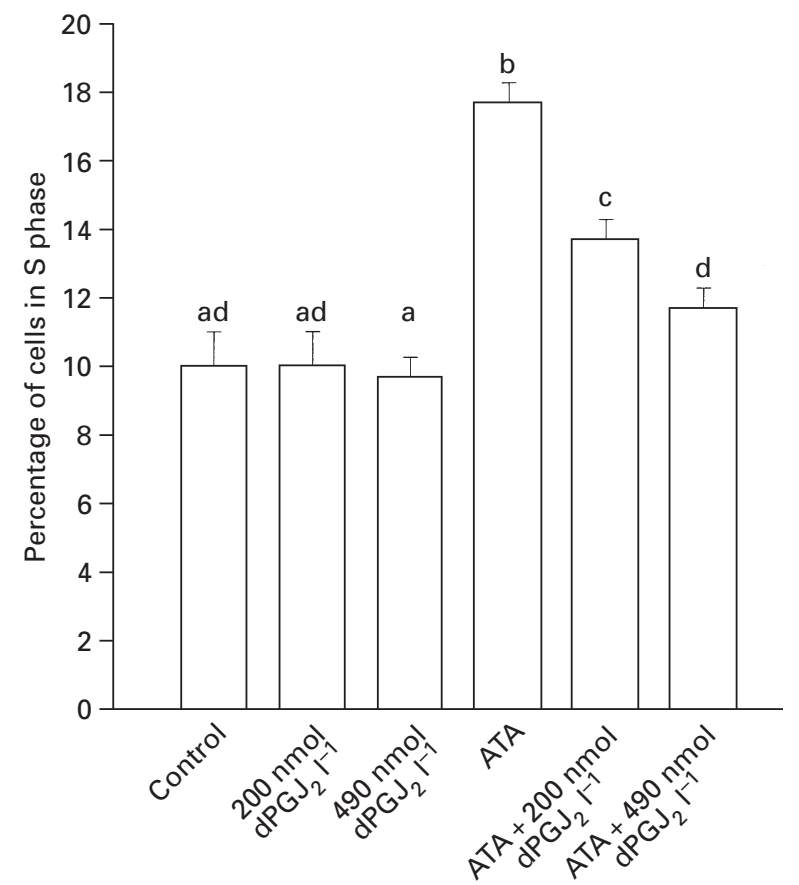

Fig. 2. Peroxisome proliferator-activated receptor $\gamma(\operatorname{PPAR}-\gamma)$ agonist 15-deoxy- $\Delta^{12,14}$ prostaglandin $\mathrm{J}_{2}\left(15 \mathrm{dPGJ}_{2}\right)$ inhibits the effect of $10 \mu \mathrm{mol}$ aurintricarboxylic acid (ATA) $\mathrm{l}^{-1}$ on the proportion of cells in $S$ phase in large lutein cells from non-pregnant heifers (day $12, n=3$ ) after incubation $\left(24 \mathrm{~h}, 37^{\circ} \mathrm{C}\right)$ without (control) and with effectors. Bars show mean $\pm \mathrm{SD}$. Values with different letters show differences between control and treatment groups $(P<0.05)$. presented (Table 1). The proportions of PCNA-positive cells in the $G_{0} / G_{1}$ phase relative to the total number of cells in $\mathrm{G}_{0} / \mathrm{G}_{1}$ were $30 \%$ and $7 \%$ in cells from days 5 and 12 , respectively, indicating activated $\mathrm{G}_{1}$-lutein cells occurred predominantly in the cell pool from day 5 . In the analysis of PCNA, non-specific mouse $\operatorname{IgG}_{2 a}$-FITC was used as a negative control (Fig. 3a (quadrant I + II) and Table 1; $18 \pm$ $3 \%, n=4$, two non-pregnant animals per group). In nonpregnant heifers, the proportion of PCNA-positive cells on day 5 was higher $(38 \pm 4 \%, n=3)$ than the proportion observed on day 12 (Fig. 3b,c (quadrant I+II), and Table 1; $20 \pm 3 \%, n=3$ ). An ectopic expression of PCNA in lutein cells on day 12 was not detected (Table 1) and the expression in cells from non-pregnant heifers on day 20 was not different from the control (data not shown).

\section{Comparison of PPAR- $\gamma$ protein expression in lutein cells between non-pregnant and pregnant heifers}

Flow cytometrical quantification of the PPAR- $\gamma$ protein in day 5, day 12 and day 20 non-pregnant and pregnant heifers is shown (Fig. 4). A decrease in the proportion of PPAR- $\gamma$ positive cells was detected in large lutein cells of the corpus luteum from non-pregnant heifers on day $5>$ day $12>$ day 20 (Fig. 4a). In contrast, the portion of PPAR- $\gamma$-positive cells in pregnant heifers only differed significantly between day 5 and day 20 (Fig. 4a). The number per cell was significantly $(P<0.05, n=3)$ higher in pregnant heifers compared with non-pregnant heifers (Fig. 4b). There were marked differences in the cellular PPAR- $\gamma$ concentration among the 
(a)

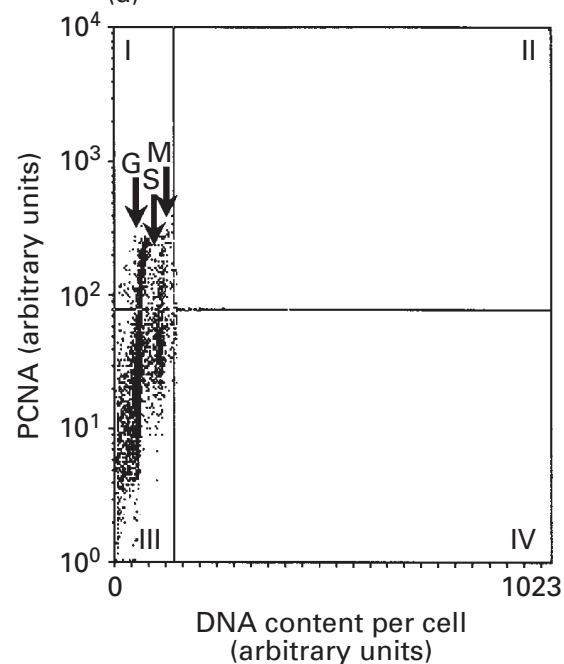

(b)

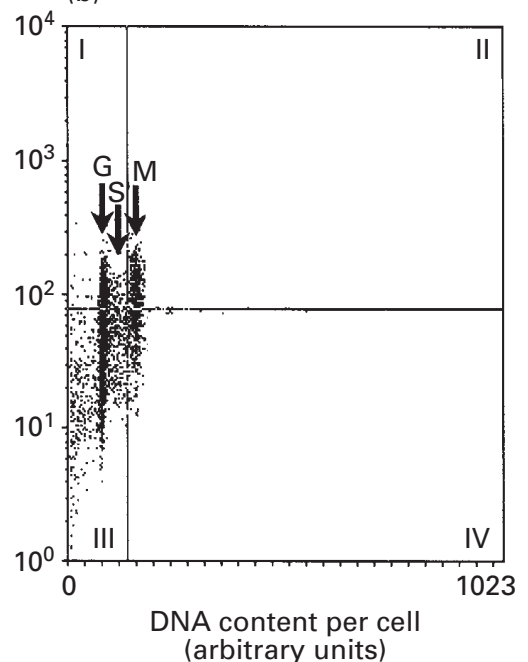

(c)

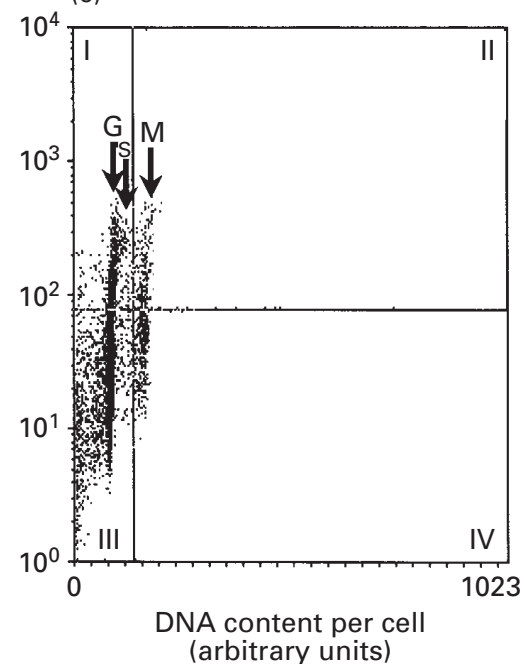

Fig. 3. Relationship between DNA content and proliferating cell nuclear antigen (PCNA) in large lutein cells from non-pregnant heifers. PCNA and DNA contents were recorded simultaneously by immunofluorescence and by the fluorescent nucleic acid stain propidium iodide via computer-aided flow cytometric dual fluorescence analysis. The histograms of the fluorescent large lutein cells displayed by the flow cytometer are shown. With increasing DNA content per cell (propidium iodide stain) the cells dual-stained by propidium iodide and PCNA immunofluorescence shift into quadrant II. (a) Control data, that is, non-specific fluorescence of the PCNA stain; (b,c) day 5 and day 12 of the oestrous cycle, respectively ( $n=3$ for each day). G, S and M refer to phases of the cell cycle. The quantified data are presented in Table 1 .
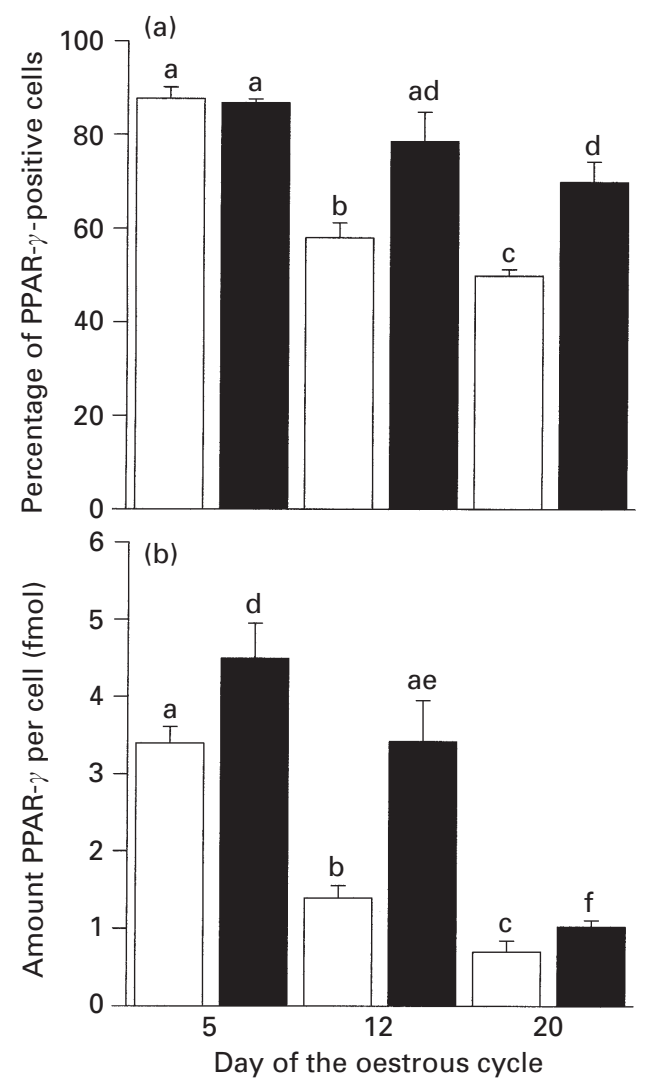

Fig. 4. Peroxisome proliferator-activated receptor $\gamma($ PPAR- $\gamma)$ in large lutein cells from non-pregnant $(\square)$ and pregnant $(\square)$ heifers $(n=3$ in each group). (a) Percentage of PPAR- $\gamma$-positive cells and (b) amount of PPAR- $\gamma$ per cell (fmol). Values with different letters show differences between day of the oestrous cycle within and between the groups of pregnant and non-pregnant animals $(P<0.05)$. different stages of the corpus luteum (Fig. 4b). The cellular PPAR- $\gamma$ content of day 5 and day 20 lutein cells decreased from $4.5 \pm 0.5$ to $1.0 \pm 0.8 \mathrm{fmol}$ per cell in pregnant heifers (Fig. 4b). In non-pregnant heifers, the corresponding values were $3.4 \pm 0.3$ and $0.5 \pm 0.2 \mathrm{fmol}$ per cell.

\section{Detection of PPAR- $\gamma$ isoforms}

Lutein cells express PPAR- $\gamma_{1}$ with a molecular mass of $52 \mathrm{kDa}$ and PPAR- $\gamma_{2}$ with a molecular mass of $56 \mathrm{kDa}$ (Fig. 5). The results of the analysis of the changes in the molecular pattern of PPAR- $\gamma$ are also presented (Fig. 5). The different stages of the corpus luteum are distinguished by an alteration in the ratio of PPAR- $\gamma_{1}$ :PPAR- $\gamma_{2}$. A decrease in the PPAR- $\gamma_{1}$ isoform is detectable in day 12 large lutein cells $(50 \%$ of the value on day $5, P<0.05$ ) of non-pregnant animals (Fig. 5).

Information about the physiological background of the reduction in the PPAR $-\gamma$ proteins was obtained by treating

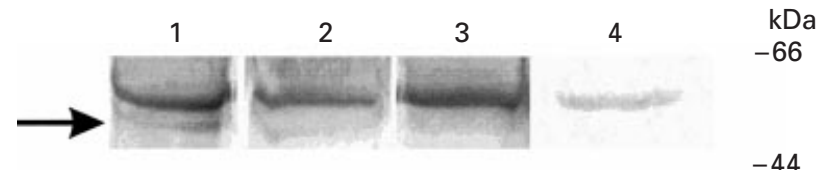

Fig. 5. $\mathrm{PGF}_{2 \alpha}$-mediated change in peroxisome proliferator-activated receptor (PPAR) $\gamma_{1}$ and $\gamma_{2}$ isoforms in lutein cells from non-pregnant heifers treated without the carrier (control) and with $\mathrm{PGF}_{2 \alpha}$ analogue. A representative result of the immunoblot analysis is shown. Lane 1: control cells on day 5 of the oestrous cycle; lane 2: cells from $\mathrm{PGF}_{2 \alpha}$-treated heifers on day 5; lane 3: control cells on day 12; lane 4: cells from $\mathrm{PGF}_{2 \alpha}$-treated heifers on day 12. The arrow indicates the PPAR- $\gamma_{1}$ isoform of $52 \mathrm{kDa}$. 
non-pregnant animals on day $4+12 \mathrm{~h}$ with the PPAR- $\gamma$ antagonist $\mathrm{PGF}_{2 \alpha^{\prime}}$ as at this stage the cells of the corpus luteum apparently express the complete set of PPAR- $\gamma$ proteins. The PPAR- $\gamma_{1}$ protein was markedly reduced ( $40 \%$ of the non-treated control value, $P<0.02)$, whereas the PPAR- $\gamma_{2}$ isoform decreased less markedly (Fig. 5).

\section{Discussion}

PPAR- $\gamma$ is expressed in numerous tissues albeit at different concentrations (Braissant et al., 1996). Nunez et al. (1997) reported that mRNA from PPAR is present in oestrogendependent reproductive tissues and PPARs can activate oestrogen-dependent genes. However, this report only provided evidence for the expression of PPAR- $\alpha$ mRNA in granulosa and theca cells of the ovary and in the corpus luteum. Investigations on PPAR- $\gamma$ expression in female reproductive cells are lacking, except for the study of Löhrke et al. (1998) in which expression of PPAR- $\gamma$ mRNA and protein was reported in bovine lutein cells. The results also showed that the PPAR- $\gamma$ proteins are active and are involved in the control of progesterone production, a functional differentiation marker of lutein cells (Murdoch, 1995; Juengel et al., 1995).

The results of the present study show that the concentration of PPAR- $\gamma$ proteins differs among different luteal stages. The highest expression of PPAR- $\gamma$ was observed in the cells at early dioestrus (day 5). This expression decreased during mid-dioestrus (day 12) and during pro-oestrus (day 20). The expression of PPAR- $\gamma$ was significantly higher in the cells from pregnant heifers, compared with non-pregnant heifers. Information about the pathways mediating the temporal course of the expression of PPAR- $\gamma$ proteins was obtained by treating animals at early dioestrus with an antagonist to PPAR $-\gamma, \mathrm{PGF}_{2 \alpha}$ (Reginato et al., 1998). The lutein cells responded with a decrease in the PPAR- $\gamma$ proteins, especially PPAR $-\gamma_{1}$, indicating PPAR $-\gamma$ is a target for the action of the prostaglandin, which is reported to have strong luteolytic activity in many mammalian species (Tsai and Wiltbank, 1998). These results indicate PPAR- $\gamma$ has a role in the maintenance of a differentiated state in large lutein cells. In other mammalian cells, both PPAR- $\gamma$ isoforms are negatively regulated by tumour necrosis factor $\alpha$ (TNF- $\alpha$ ) (Zhang et al., 1996), a cytokine that may be involved in luteolysis (Gaytan et al., 1998). However, low constitutive expression of PPAR- $\gamma$ was sufficient to block partially the inhibitory effects of TNF- $\alpha$ on the expression of genes regulated by PPAR- $\gamma$ (Zhang et al., 1996). The ratio of the two isoforms of PPAR- $\gamma$ varies both among species and tissues (Vidal-Puig et al., 1997; Ma et al., 1998). PPAR- $\gamma_{1}$ has been found in rodents as a minor component in adipose and non-adipose tissues, whereas PPAR- $\gamma_{1}$ mRNA in bovine spleen, lung and ovary was expressed at a higher level than PPAR- $\gamma_{2}$ mRNA (Sundvold et al., 1997). Ma et al. (1998) suggested that the function of the PPAR- $\gamma_{1}$ and PPAR- $\gamma_{2}$ isoforms in avian oestrogen-responsive uropygial gland was different: PPAR $\gamma_{1}$ may be involved in peroxisome proliferation, whereas PPAR- $\gamma_{2}$ may be involved in the regulation of lipid metabolism. In contrast, to date, nothing is known about the role of the PPAR- $\gamma$ isoforms in lutein cell differentiation. Regulation of lutein cell differentiation should involve control of the cell cycle. Studies in domestic ruminants indicate that small (theca-derived) lutein cells proliferate, whereas large (granulosa-derived) lutein cells do not (Sawyer, 1995). The proliferative activity in bovine lutein steroidogenic cells in different stages of the corpus luteum is incompletely understood (Niswender et al., 1994). The results of the present study demonstrate that the proportion of large lutein cells in the $S$ phase of the cell cycle that express PCNA decreased during mid-dioestrus (day 12) compared with early dioestrus (day 5). This observation corresponds to the morphological changes in the corpus luteum and with the concentration of PPAR- $\gamma$ per lutein cell. PPAR- $\gamma$ exerts an inhibitory effect on transcription factors, such as those of the signal-transducing activators of transcription (STAT) family (Ricote et al., 1998), and binds cofactors, including members of the src family (Shao et al., 1998) that are involved in regulation of the cell cycle. However, the mode of action of PPAR- $\gamma$ on the cell cycle in lutein cells remains to be elucidated. A prerequisite for PPAR- $\gamma$ activities on the transcription of target genes is activation by an agonist, including long chain fatty acids and type $\mathrm{PGD}_{2}$ prostanoids (Forman et al., 1995; Kliewer et al., 1995). The most potent $\mathrm{PGD}_{2}$ derivative, $15 \mathrm{dPGJ}_{2}$, is produced by macrophages that also express PPAR- $\gamma$ (Ricote et al., 1998) and are present in the corpus luteum (Gaytan et al., 1998; Penny et al., 1998; Zhao et al., 1998). The number of macrophages identified by the surface antigen CD68 is parallel to the functional activity of the human corpus luteum, indicating bi-directional communication between macrophages and steroidogenic cells or regulation of both cell populations of the corpus luteum by a similar mechanism (Gaytan et al., 1998). The results of the present study indicate that the corresponding signal transduction may be mediated by PPAR- $\gamma$. The activity of macrophages may change with changes in the concentrations of activating and suppressing factors, such as interferon $\tau$ and progesterone. The steroid is known to act as a potent antagonist of some activities of macrophages, including superoxide production (Sugino et al., 1996). Hence, a decrease in ovarian production of PPAR- $\gamma$ agonists appears to reduce the ectopic expression of PPAR- $\gamma$ in a timedependent manner. However, the action of macrophages on lutein cells, via the potent PPAR- $\gamma$ agonist $15 \mathrm{dPGJ}_{2}$, is unknown, whereas the luteotrophic effects of type D prostaglandins are established in vitro and in vivo (ZelinskiWooten and Stouffer, 1990).

The present investigation of the effect of $15 \mathrm{dPGJ}_{2}$ focused on lutein cells at mid-dioestrus since they are thought to contribute most of the circulating progestins, whereas oestrogens disappear from circulation (Park-Sarge et al., 1995). These cells almost ceased their proliferative activity as demonstrated in the present study and by Fields et al. (1992). ATA is a drug that stimulates progress of the cell cycle in lutein cells at mid-dioestrus (Löhrke et al., 1998). In addition, ATA exerts anti-apoptogenic effects on several types of cell (Catchpoole and Stewart, 1994; Posner et al., 1995) including lutein cells (Löhrke et al., 1998; Viergutz et al., 1999). Hence, the effect of $15 \mathrm{dPGJ}_{2}$ on cell cycle activity was investigated using the ATA model. The results showed that the PPAR- $\gamma$ agonist 
suppresses an ATA-induced increase in the percentage of cells in S phase in a dose-dependent manner. These results indicate the reversibility of the cell cycle arrest in mid-dioestrous cells and a role for PPAR- $\gamma$ in arresting the cell cycle to maintain the differentiated function of lutein cells.

In summary, the results of the present study demonstrate a downregulation of the expression PPAR- $\gamma$ and PCNA proteins in large lutein cells of the ageing corpus luteum, indicating a role in the maintenance of differentiated luteal cells. This proposal is supported by the experiments showing that the near arrest of cell cycle activity in lutein cells at middioestrus can be stimulated by ATA and the natural PPAR- $\gamma$ agonist, $15 \mathrm{dPGJ}_{2}$, reverses the response. In addition, the naturally occurring decrease in the percentage of cells expressing PPAR- $\gamma$ and in the concentration of PPAR- $\gamma$ per cell can be simulated by exposing lutein cells from early dioestrus to $\mathrm{PGF}_{2 \alpha^{\prime}}$ which acts luteolytically on the middioestrus corpus luteum and inactivates PPAR- $\gamma$. The cells respond to the prostanoid by downregulating PPAR- $\gamma$, predominantly by decreasing the PPAR $-\gamma_{1}$ protein, indicating that this isoform is a target for the luteolytic action of $\mathrm{PGF}_{2 \alpha}$.

\section{References}

Amsterdam A and Rotmensch S (1987) Structure-function relationships during granulosa cell differentiation Endocrine Reviews 8 309-337

Bowen JM, Keyes PL, Warren JS and Townson DH (1996) Prolactin-induced regression of the rat corpus luteum: expression of monocyte chemoattractant protein-1 and invasion of macrophages Biology of Reproduction 54 1120-1127

Braissant O, Foufelle F, Scotto C, Dauca M and Wahli W (1996) Differential expression of peroxisome proliferator-activated receptors (PPARs): tissue distribution of PPAR-alpha, -beta, and -gamma in the adult rat Endocrinology 137 354-366

Catchpoole DR and Stewart BW (1994) Inhibition of topoisomerase II by aurintricarboxylic acid: implications for mechanisms of apoptosis Anticancer Research 14 853-856

Doody KJ, Lorence MC, Mason JI and Simpson ER (1990) Expression of messenger ribonucleic acid species encoding steroidogenic enzymes in human follicles and corpora lutea throughout the menstrual cycle Journal of Clinical Endocrinology and Metabolism 70 1041-1045

Fajas L, Fruchart JC and Auwerx J (1998) PPARgamma3 mRNA: a distinct PPARgamma mRNA subtype transcribed from an independent promoter FEBS Letters 438 55-60

Fields MJ, Barros CM, Watkins WB and Fields PA (1992) Characterization of large luteal cells and their secretory granules during the estrous cycle of the cow Biology of Reproduction 46 535-545

Forman BM, Tontonoz P, Chen J, Brun RP, Spiegelman BM and Evans RM (1995) 15-Deoxy-delta 12, 14-prostaglandin J2 is a ligand for the adipocyte determination factor PPAR gamma Cell 83 803-812

Funkenstein B, Waterman MR and Simpson ER (1984) Induction of synthesis of cholesterol side chain cleavage cytochrome P-450 and adrenodoxin by follicle-stimulating hormone, 8-bromo-cyclic AMP, and low density lipoprotein in cultured bovine granulosa cells Journal of Biological Chemistry $2598572-8577$

Gaytan F, Morales C, Garcia-Pardo L, Reymundo C, Bellido C and SanchezCriado JE (1998) Macrophages, cell proliferation, and cell death in the human menstrual corpus luteum Biology of Reproduction 59 417-425

Juengel JL, Garverick HA, Johnson AL, Youngquist RS and Smith MF (1993) Apoptosis during luteal regression in cattle Endocrinology 132 249-254

Juengel JL, Meberg BM, Turzillo AM, Nett TM and Niswender GD (1995) Hormonal regulation of messenger ribonucleic acid encoding steroidogenic acute regulatory protein in ovine corpora lutea Endocrinology 136 5423-5429

Kliewer SA, Lenhard JM, Willson TM, Patel I, Morris DC and Lehmann JM (1995) A prostaglandin J2 metabolite binds peroxisome proliferatoractivated receptor gamma and promotes adipocyte differentiation Cell $\mathbf{8 3}$ 813-819
Kliewer SA, Sundseth SS, Jones SA et al. (1997) Fatty acids and eicosanoids regulate gene expression through direct interactions with peroxisome proliferator-activated receptors alpha and gamma Proceedings National Academy of Sciences USA 94 4318-4323

Lemberger T, Staels B, Saladin R, Desvergne B, Auwerx J and Wahli W (1994) Regulation of the peroxisome proliferator-activated receptor alpha gene by glucocorticoids Journal of Biological Chemistry 26924 527-24 530

Löhrke B, Kunkel S, Köwitz J et al. (1993) Prolactin heterogeneity: a limitation on the evaluation of results from prolactin assays due to differences in immunoassays and the different bioactivities of prolactin forms European Journal of Clinical Chemistry and Clinical Biochemistry 31 815-827

Löhrke B, Derno M, Krüger B, Viergutz T, Matthes H and Jentsch W (1997) Expression of sulphonylurea receptors in bovine monocytes from animals with a different metabolic rate Pfügers Archiv 434 712-720

Löhrke B, Viergutz T, Shahi S et al. (1998) Detection and functional characterization of the transcription factor PPAR in lutein cells Journal of Endocrinology 159 429-439

Ma H, Tam QT and Kolattukudy PE (1998) Peroxisome proliferator-activated receptor gamma1 (PPAR-gamma1) as a major PPAR in a tissue in which estrogen induces peroxisome proliferation FEBS Letters 434 394-400

Marx N, Schönbeck U, Lazar MA, Libby P and Plutzky J (1998) Peroxisome proliferator-activated receptor gamma activators inhibit gene expression and migration in human vascular smooth muscle cells Circulation Research 83 1097-1103

Mendis-Handagama S, Aten R, Warkins P, Scallen T and Behrman H (1995) Peroxisomes and sterol carrier protein-2 in luteal cell steroidogenesis Tissue and Cell 27 483-490

Monniaux D, Pisselet C and Fontaine J (1994) Uncoupling between proliferation and differentiation of ovine granulosa cells in vitro. Journal of Endocrinology 142 497-510

Murdoch WJ (1995) Temporal relationships between stress protein induction, progesterone withdrawal, and apoptosis in corpora lutea of ewes treated with prostaglandin F2 alpha Journal of Animal Science 73 1789-1792

Nicosia SV, Diaz J, Nicosia RF, Saunders BO and Muro-Cacho C (1995) Cell proliferation and apoptosis during development and ageing of the rabbit corpus luteum Annals of Clinical and Laboratory Science 25 143-157

Niswender GD, Juengel JL, McGuire WJ, Belfiore CJ and Wiltbank MC (1994) Luteal function: the estrous cycle and early pregnancy Biology of Reproduction 50 239-247

Nunez SB, Medin JA, Braissant O et al. (1997) Retinoid X receptor and peroxisome proliferator-activated receptor activate an estrogen responsive gene independent of the estrogen receptor Molecular and Cellular Endocrinology 127 27-40

Pall M, Hellberg P, Brännström M et al. (1997) The transcription factor C/EBP-beta and its role in ovarian function; evidence for direct involvement in the ovulatory process EMBO Journal 16 5273-5279

Park-Sarge OK, Parmer TG, Gu Y and Gibori G (1995) Does the rat corpus luteum express the progesterone receptor gene? Endocrinology 136 1537-1543

Penny LA, Armstrong DG, Baxter G et al. (1998) Expression of monocyte chemoattractant protein-1 in the bovine corpus luteum around the time of natural luteolysis Biology of Reproduction 59 1464-1469

Piontkewitz Y, Enerbäck S and Hedin L (1996) Expression of CCAAT enhancer binding protein-alpha (C/EBP alpha) in the rat ovary: implications for follicular development and ovulation Developmental Biology 179 288-296

Posner A, Raser KJ, Hajimomammadreza PW, Yuess PW and Wang KK (1995) Aurintricarboxylic acid is an inhibitor of $\mu$ - and m-calpain Biochemistry and Molecular Biology International 36 291-299

Reginato MJ, Krakow SL, Bailey ST and Lazar MA (1998) Prostaglandins promote and block adipogenesis through opposing effects on peroxisome proliferator-activated receptor gamma Journal of Biological Chemistry 273 1855-1858

Richards RG and Almond GW (1994) Tumour necrosis factor-alpha differentially alters progesterone and prostaglandin F2 alpha production by porcine luteal cells Journal of Endocrinology 143 75-83

Ricote M, Li AC, Willson TM, Kelly CJ and Glass CK (1998) The peroxisome proliferator-activated receptor-gamma is a negative regulator of macrophage activation Nature 391 79-82

Rodriguez JC, Gil-Gomez G, Hegardt FG and Haro D (1994) Peroxisome proliferator-activated receptor mediates induction of the mitochondrial 3hydroxy-3-methylglutaryl-CoA synthase gene by fatty acids Journal of Biological Chemistry 26918 767-18772 
Satoh H, Tsukamoto K, Hashimoto $\mathbf{Y}$ et al. (1999) Thiazolidinediones suppress endothelin-1 secretion from bovine vascular endothelial cells: a new possible role of PPARgamma on vascular endothelial function Biochemical and Biophysical Research Communication 254 757-763

Sawyer HR (1995) Structural and functional properties of the corpus luteum of pregnancy Journal of Reproduction and Fertility Supplement 49 97-110

Schoonjans K, Staels B and Auwerx J (1996) The peroxisome proliferator activated receptors (PPARS) and their effects on lipid metabolism and adipocyte differentiation Biochimica et Biophysica Acta 1302 93-109

Selvaraj N, Shetty G, Vijayalakshmi K, Bhatnagar AS and Moudgal NR (1994) Effect of blocking oestrogen synthesis with a new generation aromatase inhibitor CGS 16949A on follicular maturation induced by pregnant mare serum gonadotrophin in the immature rat Journal of Endocrinology 142 563-570

Shao D, Rangwala SM, Bailey ST, Krakow SL, Reginato MJ and Lazar MA (1998) Interdomain communication regulating ligand binding by PPARgamma Nature 396 377-380

Sirois J and Richards JS (1993) Transcriptional regulation of the rat prostaglandin endoperoxide synthase 2 gene in granulosa cells. Evidence for the role of a cis-acting C/EBP beta promoter element Journal of Biological Chemistry 26821 931-21938

Sterneck E, Tessarollo L and Johnson PF (1997) An essential role for C/EBPbeta in female reproduction Genes and Development 11 2153-2162

Stöhr M, Vogt-Schaden M, Knobloch M and Vogel R (1978) Evaluation of eight fluorochrome combinations for simultaneous DNA-protein flow analyses Stain Technology 53 205-215

Sugino N, Shimamura K, Tamura H et al. (1996) Progesterone inhibits superoxide radical production by mononuclear phagocytes in pseudopregnant rats Endocrinology 137 749-754

Sundvold H, Brzozowska A and Lien S (1997) Characterisation of bovine peroxisome proliferator-activated receptors gamma 1 and gamma 2: genetic mapping and differential expression of the two isoforms Biochemical and Biophysical Research Communication 239 857-861

Tsai SJ and Wiltbank MC (1998) Prostaglandin F2alpha regulates distinct physiological changes in early and mid-cycle bovine corpora lutea Biology of Reproduction 58 346-352

Vidal-Puig AJ, Considine RV, Jimenez-Linan M et al. (1997) Peroxisome proliferator-activated receptor gene expression in human tissues. Effects of obesity, weight loss, and regulation by insulin and glucocorticoids Journal of Clinical Investigation 99 2416-2422

Viergutz T, Krüger B and Löhrke B (1999) N-acetylcysteine-mediated induction of apoptosis by peroxisomale oxidative stress in bovine lutein cells European Journal of Cell Biology 7828

Wu Z, Xie Y, Bucher NL and Farmer SR (1995) Conditional ectopic expression of C/EBP beta in NIH-3T3 cells induces PPAR gamma and stimulates adipogenesis Genes and Development 9 2350-2363

Xing H, Northrop JP, Grove JR, Kilpatrick KE, Su JL and Ringold GM (1997) TNF alpha-mediated inhibition and reversal of adipocyte differentiation is accompanied by suppressed expression of PPARgamma without effects on Pref-1 expression Endocrinology 138 2776-2783

Zelinski-Wooten MB and Stouffer RL (1990) Intraluteal infusions of prostaglandins of the E, D, I, and A series prevent PGF2 alpha-induced, but not spontaneous, luteal regression in rhesus monkeys Biology of Reproduction 43 507-516

Zhang B, Berger J, Hu E et al. (1996) Negative regulation of peroxisome proliferator-activated receptor-gamma gene expression contributes to the antiadipogenic effects of tumor necrosis factor-alpha Molecular Endocrinology 10 1457-1466

Zhao Y, Burbach JA, Roby KF, Terranova PF and Brannian JD (1998) Macrophages are the major source of tumor necrosis factor alpha in the porcine corpus luteum Biology of Reproduction 59 1385-1391 